\title{
Consequence of QMS ISO 9000 and EMSISO 14000 Implementation on CZ/ SK Enterprise Performance with Respect to Sustainability
}

\author{
Adam Pawliczek and Radomír Piszczur \\ Silesian University in Opava, Faculty of Business Administration in Karvina, Karvina, Czech Republic
}

Correspondence should be addressed to: Angel Bakardjiev; pawliczek@opf.slu.cz

Copyright (C) 2013 Adam Pawliczek and Radomír Piszczur. Distributed under Creative Commons CC-BY 3.0

\begin{abstract}
This paper deals with the influence of implemented quality and environmental management systems ISO 9000 and ISO 14000 on enterprise performance. The paper delivers original results and comments on realized and processed questionnaire research concerning approx. 700 companies operating through Czech and Slovak Republics, called "Adaptability of entrepreneurship", financed by Silesian University in Opava. The paper evaluates the difference in enterprise performances as an effect of implementation of ISO management systems. The performance of 4 groups of companies (no ISO implemented, ISO 9000 implemented, ISO 14000 implemented and both ISO 9000 and 14000 implemented) is compared. 14 criteria were selected for evaluation, which can be marked as enterprise sustainability aspects. Three hypotheses were tested. The results show visible improvement in performance and awareness of selected priorities at companies with implemented ISO management systems. Problematic and results are discussed and compared with similar researches published inprofessional literature.The most important results of the paper were presented on 19th IBIMA Conference in Barcelona on November 12-13, 2012 .
\end{abstract}

Keywords: ISO 9000, ISO 14000, enterprise, sustainability, performance.

\section{Introduction}

Contemporary middle European milieu is characterized by not very stable business conditions. Turbulent business time period is well known for "cheap and easy" aftertransformation EU economics, as Czech and Slovak Republic still are perceived. Bank and economic crisis and recession push on enterprises (at strongest at SMEs) to adapt new conditions or quit, to make decisions and steps leading to continuous improvement, sustainability or loose competitive ability. Long-term and shortterm goals must be reevaluated and impact put on viable and promising opportunities. Previous research has discovered very significant underestimating of strategic management importance (Pawliczek, 2011). But exactly modern management methods and systems, as fundaments of strategic management, have to be mastered by competent management, taking in account principles of long-term, sustainable and

Cite this Article as: Adam Pawliczek and Radomír Piszczur (2013), "Consequence of QMS ISO 9000 and EMSISO 14000 Implementation on CZ/ SK Enterprise Performancewith Respect to Sustainability," Journal of Eastern Europe Research in Business \& Economics, Vol. 2013 (2013), Article ID 420617, DOI: $10.5171 / 2013.420617$ 
socially responsible business,are growing important more than ever before.

\section{Aims of the Study}

Primary goal of the study is to discover if application of ISO 9000 and/or ISO 14000 management systems as sophisticated modern management methodic complexes has positive effects on stability of business in the enterprise sustainability context on the basis of selected criteria.

\section{Theory and Hypotheses}

\section{Modern Methods of Strategic Management}

Modern strategic management brings entrepreneurs many effective tools helping them develop their business and achieve better results. Some of them are basic and easy as SWOT analysis or SMART principles. Further methods are advanced, more complex and need to be thoroughly studied, such as for example MBO, KPI, BSC. Quality management systems such as TQM, EFQM, LEAN, KAIZEN, 6 SIGMA, SA 8000 are very important and our special interest now fits in ISO 9000 and ISO 14000.

\section{ISO 9000 Quality Management System Standard}

The ISO 9000 family of international quality management standards and guidelines has earned a global reputation as a basis for establishing effective and efficient quality management systems. Figure 1 describes ISO 9000 process approach. Since their initial publication in 1987, the ISO 9000 standards have undergone three revision cycles and have had a great impact on the implementation of international trade and quality management systems by organizations throughout the world. It is widely acknowledged that proper quality management improves business, often having a positive effect on investment, market share, sales growth, sales margins, competitive advantage and avoidance of litigation. The quality principles in ISO 9000:2000 are also sound, according to Wade (Wade, 2002) and Barnes (Barnes, 2000), who says that "ISO 9000 guidelines provide a comprehensive model for quality management systems that can make any company competitive." Implementing ISO often secures the following advantages (Nenadál, 2005; ISO, 2009):

- Creates a more efficient, effective operation.

- Increases customer satisfaction and retention.

- Reduces audits.

- Enhances marketing.

- Improves employee motivation, awareness and morale.

- Promotes international trade.

- Increases profit.

- Reduces waste and increases productivity.

- Common tool for standardization. 


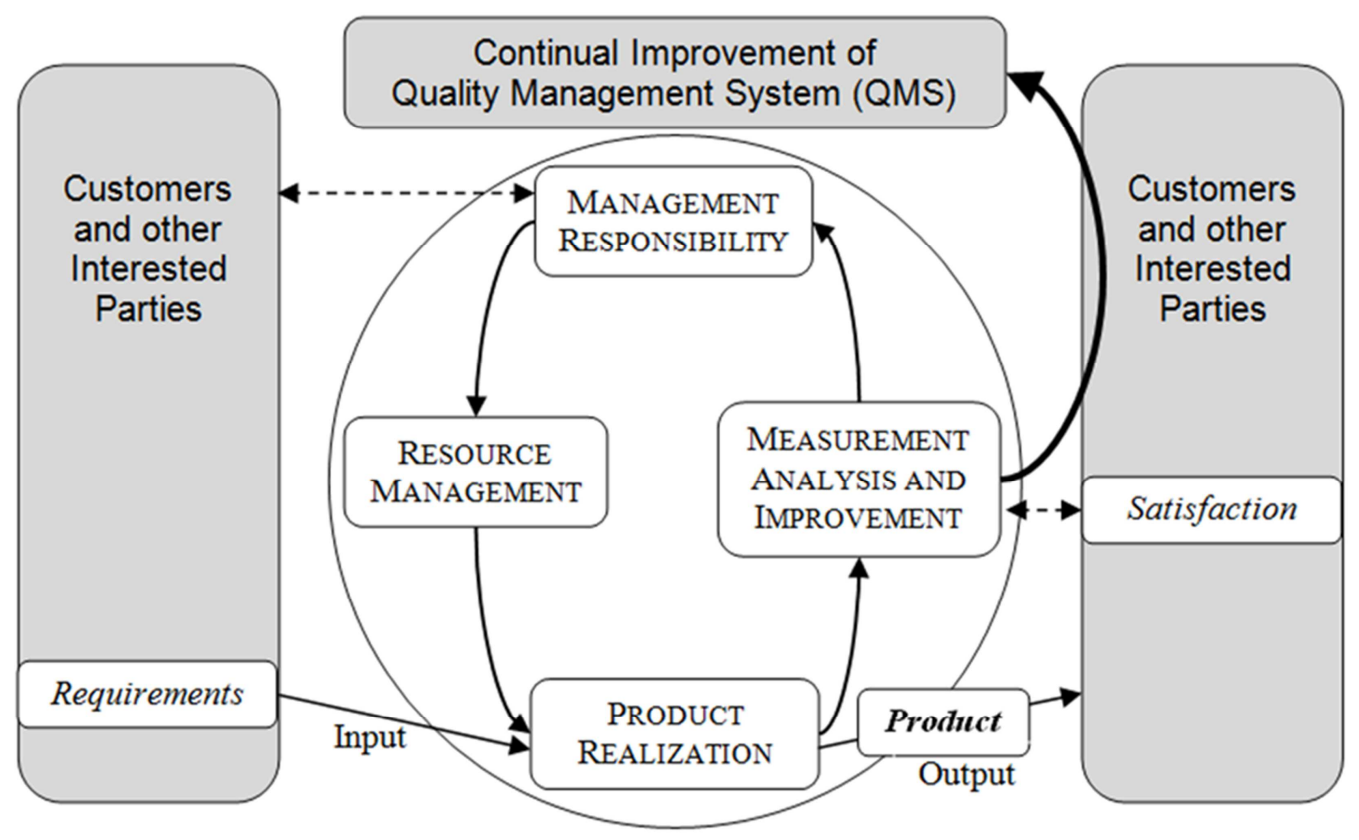

Figure 1. The ISO 9000 Process Approach

The objectives of ISO 9000 are quite simpleto improve the confidence in the organization's ability to consistently provide conform products to its customers. The way in which the enterprise manages its business activities in order to achieve this objective differs apparently and depends very much on its nature and type (most of all economic sector, size, legal form and others) and ISO provides systematic activity setting to meet company goals and requirements.

\section{ISO 14000 Environmental Management System Standard}

Organizations of all kinds are increasingly concerned with achieving and demonstrating sound environmental performance by controlling the impacts of their activities, products and services on the environment, consistent with their environmental policy and objectives. They do so in the context of increasingly stringent legislation, the development of economic policies, norms and other measures that foster environmental protection, and increased concern expressed by interested parties about environmental matters and sustainable development. The most representative EMS ISO 14000 International Standard is based on the methodology known as Plan-Do-CheckAct (PDCA). PDCA can be briefly described as follows (Nenadál, 2005; ISO, 2009):

- Plan: establish the objectives and processes necessary to deliver results in accordance with the organization's environmental policy.

- Do: implement the processes.

- Check: monitor and measure processes against environmental policy, objectives, targets, legal and other requirements, and report the results.

- Act: take actions to continually improve performance of the environmental management system. 


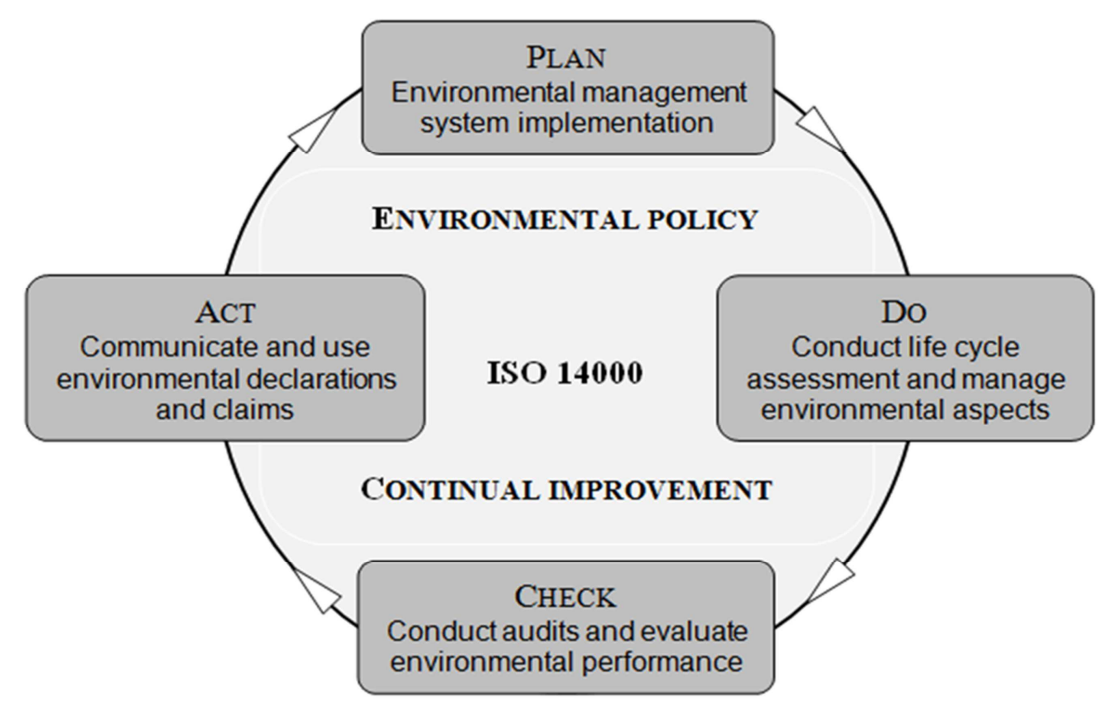

Figure 2. Environmental Management System Model by ISO 14000

International Standards covering environmental management are intended to provide organizations with the elements of an effective environmental management system (EMS) that can be integrated with other management requirements and systems and help organizations achieve environmental and economic goals. The basis of the approach is shown in figure 2. The success of the system depends on commitment from all levels and functions of the organization, and especially from top management.

\section{Progressive Stability in the Sustainability Context}

Elasticity of management, entrepreneurship adaptability and stability are closely interconnected concepts. Elasticity of management is described in literature in four dimensions as: (1) reactive, (2) adaptive, (3) defensive and (4) creative attributes of the strategy of an observed firm (Šebestová, 2012). Elasticity of enterprise management, as ability to react adequately at emerging conditions, is reflection and root of adaptability as enterprise's ability to survive consistently changing conditions. Progressive stability is understood as adaptability so strong, that it enables enterprise to not only survive but continuously improve processes, become more robust and achieve better sustainable results that can be observed on selected criteria. Koval'ová concludes that entrepreneurship performance and effectiveness is directly connected with establishing its sustainable competitiveness (Koval'ová, 2011).

Sustainability concept with the accent on small and medium businesses (SMEs) should be examined in five important aspects (Scott, 2010; Pawliczek, 2011):

- Economic aspects (E)

- Social aspect (S)

- Environmental aspect (N)

- Technological aspect (T)

- Legislative and political (L).

A Polish research of SME de-conjuncture in the period 2007-2010 has discovered these important negative symptoms: (1) fall of sales and turnover, (2) fall of profit, (3) rise of operational costs, (4) rise of mistrust, (5) rise of employees' fear of future, and more (Zakrzewska-Bielawska, 2011). Similar 
crisis/recession effect is expected to be apparent in enterprises in both Czech and Slovak Republics. Kočišová presents 2005/2006 indices of Slovak SMEs (value from interval -12 to 12 points): (1) average profit: value $7,(2)$ average turnover: value 11, (3) average number of employees: value 7, (4) investments into innovations: value -6 (Kočišová, 2010).

This paper addresses the following issues, each characterizing one or more aforementioned sustainability aspects (most close aspects):

- Trend of development of financial indicators: turnover, cost and profit of business (E);

- Investments and business development activity $(\mathrm{E}, \mathrm{T}, \mathrm{N})$

- Key customers and negotiated contracts (E, S)

- Trend of development of employment and employees' affiliations (S, E)

- Trend of development of employees benefits $(\mathrm{S})$

- Satisfaction of employees and its measurement $(\mathrm{S}, \mathrm{E})$

- Energy consumption and energy saving arrangements (N, E, T, L)

- Application of renewable energy sources RES (N, T, E, L)

- Separation and recycling of business waste $(\mathrm{N}, \mathrm{T}, \mathrm{L})$

- Usage of recycled materials and material saving arrangements (N, T, E, L).

On the basis of examined sustainability issues, these hypotheses were formulated:

HYP1: Application of ISO 9000 management system has positive effect on stability of business in the sustainability context on the basis of selected criteria.

HYP2: Application of ISO 14000 management system has positive effect on stability of business in the sustainability context on the basis of selected criteria.

HYP3: Application of ISO 9000 and ISO 14000 management systems has synergetic positive effect on stability of business in the sustainability context on the basis of selected criteria.

The validity of each hypothesis will be examined by analytical evaluation of leading questions/ criteria.

\section{Original Research on Entrepreneurship Adaptability and its Methodology}

The method used during the creation of this paper is described in this chapter. After preliminary research and inspiration from relevant scientific literature the researchers formulated the hypothesis. The hypothesis was subsequently evaluated by data analysis of questionnaire research characterized below.

\section{Questionnaire Research}

The questionnaire research was realized during the Spring semester 2012 by students of Business Entrepreneurship Faculty in Karvina, Silesian University in Opava (Czech Republic). 722 companies active in Czech and Slovak Republics in the period 2009-2011 were subjects of interest (SMEs are creating $89 \%$ of sample group in accordance with number of employees' criterion). The interview protocol includes studentcontrolled interview with enterprise owner, executive manager or top manager, so the collected data have the character of expert guess opinion. Company identification (10 questions) and identification of student and their opinion on questionnaire relevance (5 questions) made a necessary part of each form. Initial sample size, 722 companies, were filtered and reduced to 677 credible 
items. The questionnaire form also includes nondisclosure statement to provide protection of confidential data. Moreover, data was analyzed anonymously and published as only no-name data.

Data reliability is assured by (1) authorization (contact person, signature, stamp), (2) subjective student relevance evaluation, partially (3) internet verification and (4) statistical validity (standard deviation).

The questionnaire focused on seven areas of interest (23 of 51 questions evaluated):

- Enterprise's strategic management (6 questions)

- Economic and financial trends of business, risk management (5 of 11 questions evaluated),

- Personal politics of company (4 of 7 questions evaluated)

- Production, services and innovations (8 questions)

- Grants and subsidies (4 questions)

- Energetic and material savings and application of renewable sources (7 of 8 questions evaluated)

- Sustainability priorities of enterprises (7 of 7 questions evaluated).

\section{Selected and Evaluated Questions (Criteria)}

The following questions/criteria were evaluated. Numbering of questions correspond to that used in the questionnaire. Each part had enough space to comment on the questions and add further narrative information.

- Economic and financial trends of business (part C):
C1: How period 2009-2011 influenced business turnover?

C2: How period 2009-2011 influenced business costs?

C3: How period 2009-2011 influenced business profit?

C4: How period 2009-2011 influenced business assets (investments)?

C6: How long in advance company usually arranges contracts?

- Personal politics of company (part D):

D3: How period 2009-2011 influenced number of employees?

D2: How period 2009-2011 influenced present employee affiliations?

D1: How period 2009-2011 influenced employee benefits?

D9: Has the company researched or measured employees' satisfaction?

- Energetic and material savings and application of renewable sources (part G):

G7: How period 2009-2011 influenced energy consumption?

G2: Have you realized arrangements for energy savings?

G9: What percentage of needed energy do you obtain from RES?

G3: What kind of RES do you apply? complementary question

G8: Have you realized arrangements for material savings?

G4: Do you separate and recycle business waste? 
G10: How many of material inputs is recycled material? - complementary question

\section{Data Analysis}

For the sake of comparison, data was structured into four data evaluation groups:

- Enterprises with neither ISO 9000 nor ISO 14000 implemented - expected to be less stable (414 enterprises).

- Enterprises with ISO 9000 implemented (249 enterprises). $42 \%$ of companies with ISO 9000 have also ISO 14000.

- Enterprises with ISO 14000 implemented (121 enterprises). 88\% of companies with ISO 14000 have also ISO 9000.

- Enterprises with both ISO 9000 and ISO 14000 implemented - expected to be the most stable and synergic (107 enterprises).
Data were processed by Microsoft $®$ Excel. Tables and charts are presented and commented on in the next chapter. Discussion with other published related scientific results is presented later.

\section{Findings and Results}

The following paragraphs and figures describe research results concerning impact of ISO 9000 and/or ISO 14000 on selected criteria using minima-maxima differential analysis comparing group of interest with worst performance (usually without implemented ISO QMS) to group of interest with best performance. The "all data" group is presented as average value to show well apparent difference between "no ISO" group and ISO implemented groups' performance.

ISO 9000 and 14000 Management Systems and Enterprise Financial and Business Trends

Five criteria concerning financial and business trends of enterprises are evaluated below.

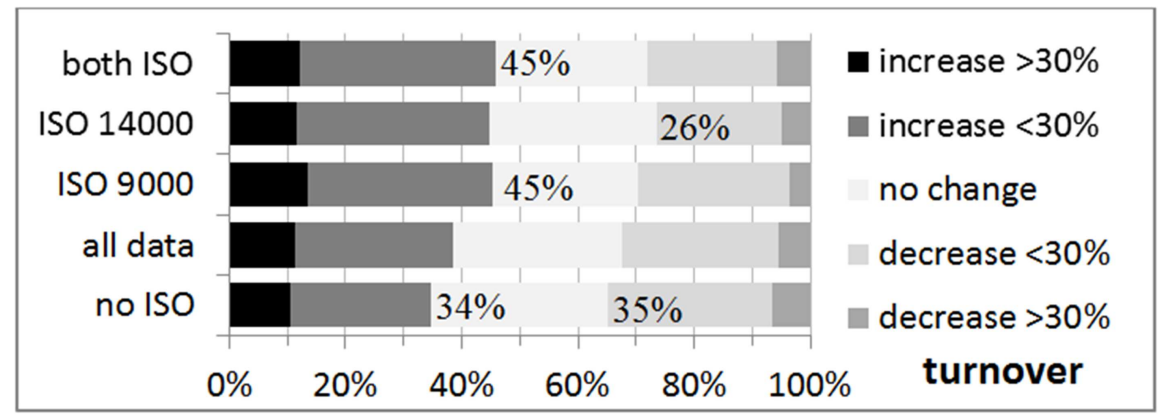

Figure 3. Evaluation of the Criterion C1 - How Period 2009-2011 Influenced Business Turnover?

$45 \%$ of enterprises which implemented both ISO EMS or at least ISO 9000 indicated increase of turnover and only $34 \%$ of enterprises which did not implement any ISO EMS indicated increase of turnover, so the maximum-minimum difference is $11 \%$. On the other side, only $26 \%$ of enterprises which did implement ISO 14000 indicated decrease of turnover with comparison to $35 \%$ which did not implement any ISO EMS and indicated decrease of turnover, so the maximum-minimum difference is $9 \%$. Together, the highest positive ISO implementation effect on enterprises is $20 \%$ higher possibility of better turnover performance compared to ISO resistant companies. 


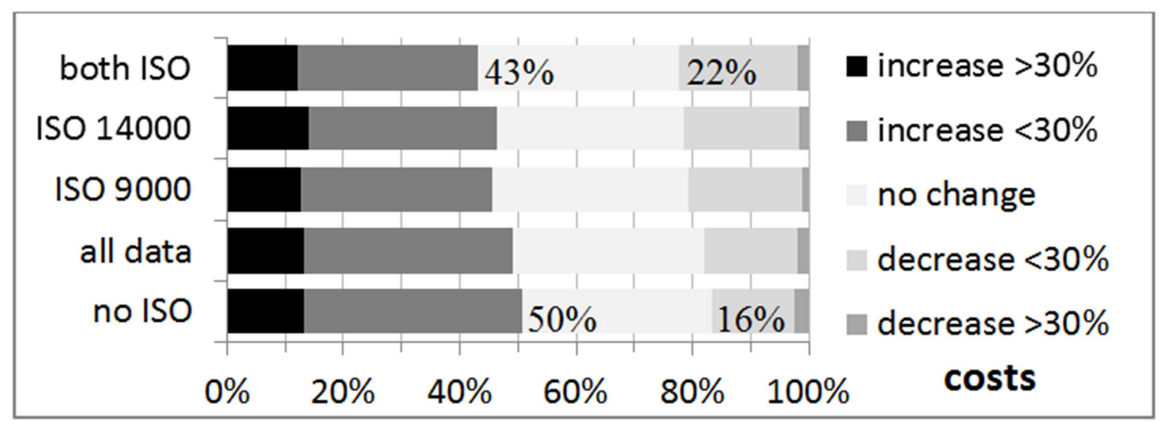

Figure 4. Evaluation of the Criterion C2 - How Period 2009-2011 Influenced Business Costs?

Only $43 \%$ of the enterprises which implemented both ISO EMS indicated increase of costs in comparison to $50 \%$ which did not implement any ISO EMS, indicating increase of costs, so the maximumminimum difference is $7 \%$. On the other side, $22 \%$ of the enterprises which implemented both ISO EMS indicated decrease of costs and only $16 \%$ enterprises which did not implement any ISO EMS declare decrease of costs, so the maximum-minimum difference is $6 \%$. Altogether, the highest positive ISO implementation effect on enterprises is $13 \%$ higher possibility of better costs performance compared to ISO resistant companies.

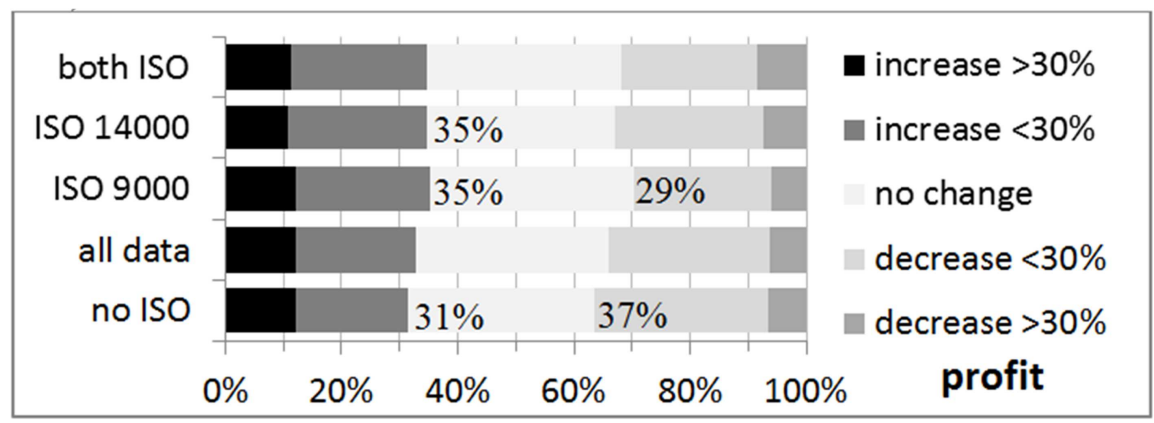

Figure 5.Evaluation of the Criterion C3 - How Period 2009-2011 Influenced Business Profit (EBIT)?

$35 \%$ of the enterprises which implemented ISO 9000 or ISO 14000 EMS indicated increase of profit and only $31 \%$ which did not implement any ISO EMS indicated increase of profit, so the maximum-minimum difference is $4 \%$. On the other side, only $29 \%$ which implemented ISO 9000 indicated decrease of profit with comparison to $37 \%$ which did not implement any ISO EMS and indicated decrease of profit, so the maximum-minimum difference is $8 \%$. Altogether, the highest positive ISO implementation effect on enterprises is $12 \%$ higher possibility of better profit performance compared to ISO resistant companies. 


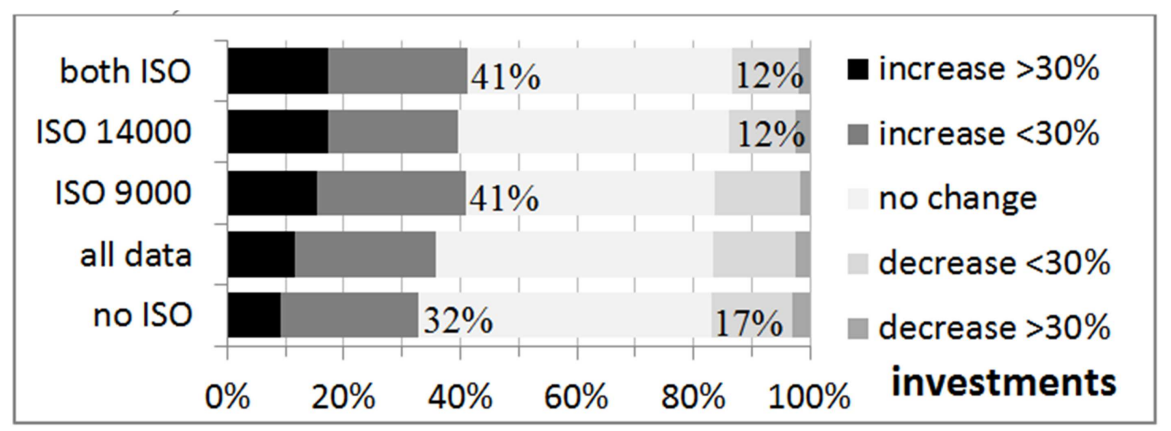

Figure 6. Evaluation of the Criterion C4 - How Period 2009-2011 Influenced Business Assets (Investments)?

$41 \%$ of the enterprises which implemented both ISO EMS or at least ISO 9000 indicated increase of assets and only $32 \%$ enterprises which did not implement any ISO EMS indicated increase of assets, so the maximum-minimum difference is $9 \%$. On the other side, only $12 \%$ which implemented either both ISO EMS or at least ISO 14000 indicated decrease of assets with comparison to $17 \%$ which did not implement any ISO EMS and indicated decrease of assets, so the maximum-minimum difference is $5 \%$. Together, the highest positive ISO implementation effect on enterprises is $14 \%$ higher possibility of better investment performance compared to ISO resistant companies.

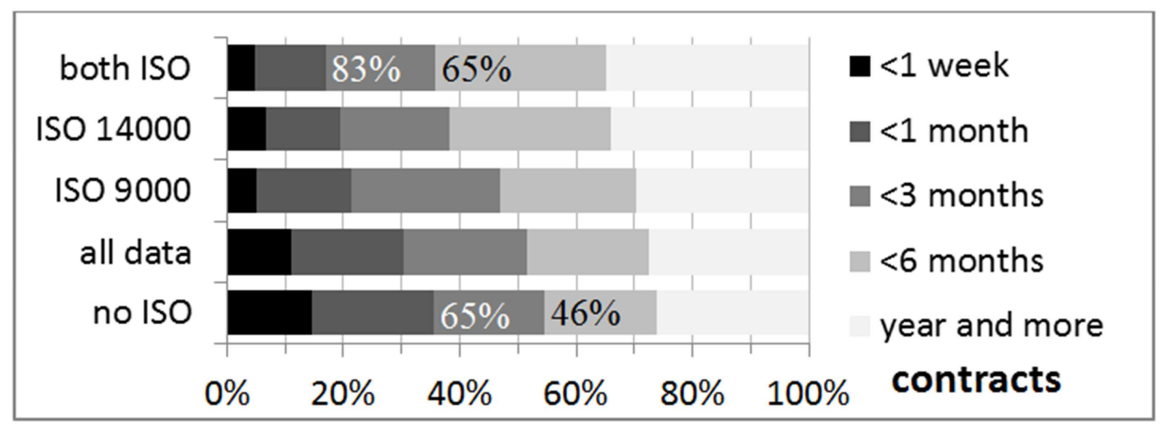

Figure 7. Evaluation of the Criterion C6 - How Long in Advance Company Usually Arranges Contracts?

The analysis is realized on two representative groups: (a) contracts arranged usually more than 1 month in advance and (b) 6 months in advance. $83 \%$ of the enterprises which implemented both ISO EMS indicated contacts arranged usually more than 1 month in advance and only $65 \%$ which did not implement any ISO EMS indicated contacts arranged usually more than 1 month in advance, so the maximumminimum difference is $18 \%$. Also 65\% which implemented both ISO EMS indicated contacts arranged usually more than 6 months in advance with comparison to $46 \%$ which did not implement any ISO EMS and indicated contacts arranged usually more than 6 months in advance, so the maximumminimum difference is $19 \%$. This criterion is most likely sensible on business branches and less applicable for some NACE branches such as for example catering services, which are characterized with fast reaction to customer demands, however this sensibility was not tested. 


\section{ISO 9000 and 14000 Management Systems and Sustainability Issues of Enterprise's Personal Politics}

Four criteria concerning personal politics are evaluated below.

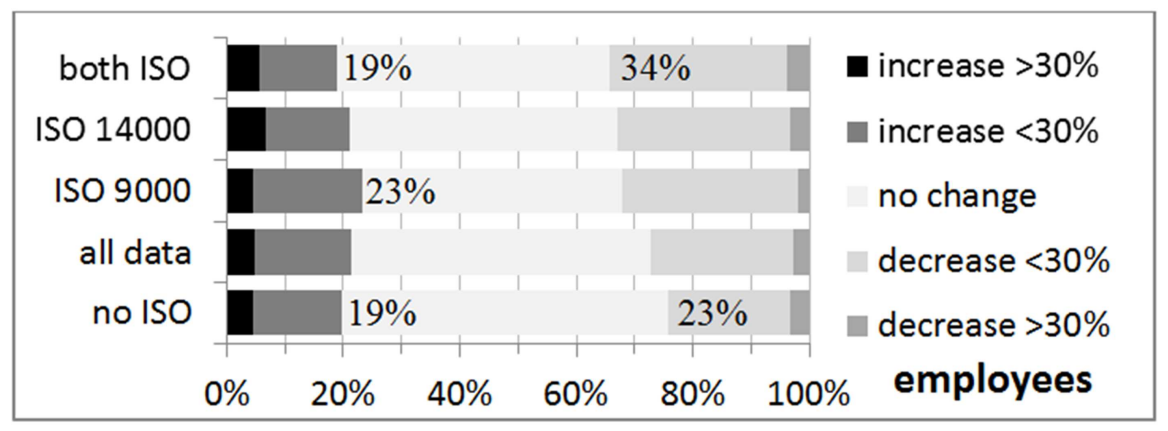

Figure 8. Evaluation of the Criterion D3 - How Period 2009-2011 Influenced Number of Employees?

$23 \%$ of the enterprises that implemented ISO 9000 showed indicated an increase in the number of employees, and only $19 \%$ which did not implement ISO or EMS indicated an increased number of employees, the maximum-minimum difference is thus $4 \%$. Surprisingly, a very low rate (19\%) of enterprises which did implement both ISO and EMS had an increased number of employees too. On the other side, $34 \%$ of the enterprises which implemented both ISO and EMS indicated a decrease in the number of employees with comparison to $23 \%$ which did not implement ISO or EMS and indicated a fall in the number of employees, so the maximum-minimum difference is $-11 \%$ (minus is placed, due to the fact that value is understood as negative, since the positive phenomenon is considered rise of employment). A similar trend shows also ISO 9000 or 14000 implemented separately. A summary observation is that the implementation of ISO (especially 14000 and both) has some negative effect on employees' number, most likely due to carried cost optimization process.

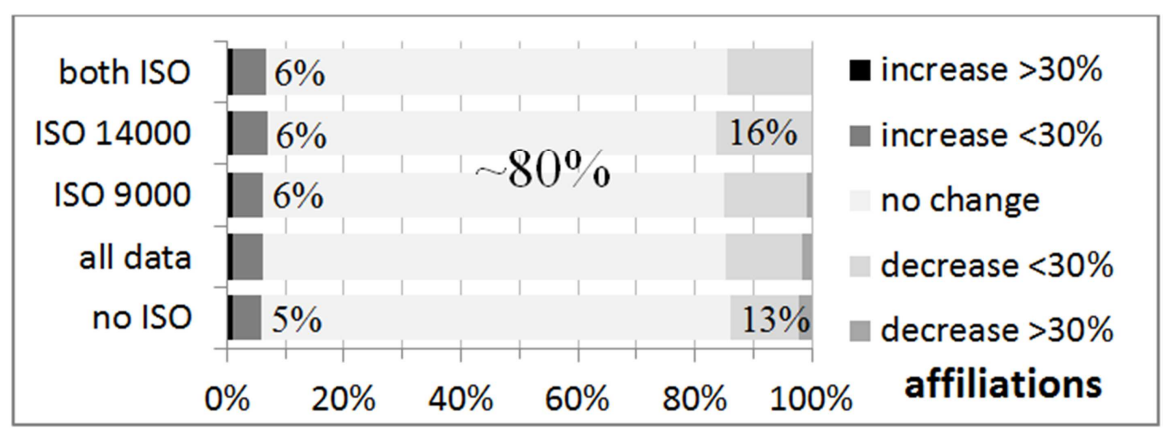

Figure 9. Evaluation of the Criterion D2 - How Period 2009-2011 Influenced Present Employee Affiliations?

$6 \%$ of the enterprises which implemented ISO 9000 and/or ISO 14000 indicated increased affiliations of present employees, and only 5\% which did not implement any
ISO EMS indicated increased affiliations of present employees, so the maximumminimum difference is $1 \%$. On the other side, $16 \%$ of the enterprises which implemented 
ISO 14000 indicated decreased affiliations of present employees in comparison to $13 \%$ enterprises which did not implement any ISO EMS and indicated decreased affiliations of present employees, so the maximumminimum difference is $-3 \%$ (minus is placed, due to the fact that value is understood as negative, since the positive phenomenon is considered rise of affiliations). A similar but subtle trend shows also ISO 9000 and both ISO implemented data groups. It can be observed, that implementation of ISO (especially 14000) has either no or slightlynegative effect on present employees' affiliations, most likely due to carried cost optimization process.

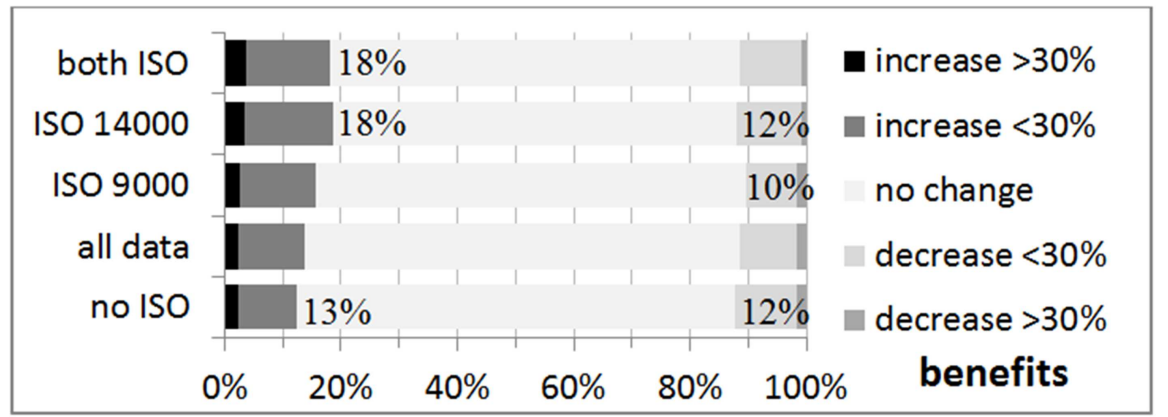

Figure 10. Evaluation of the Criterion D1 - How Period 2009-2011 Influenced Employee Benefits?

$18 \%$ of the enterprises which did implement both ISO EMS or ISO 14000 indicated increase of employees benefits, and only $13 \%$ which did not implement any ISO EMS indicated increase of employees benefits, so the maximum-minimum difference is $5 \%$. On the other hand, $12 \%$ of the enterprises which implemented ISO 14000 and those which did not implement any ISO EMS indicated decrease of employees benefits with comparison to $10 \%$ enterprises which implemented ISO 9000 and indicated decrease of employees benefits, so the maximum-minimum difference is $2 \%$ This subtle positive trend shows also both ISOimplemented groups.

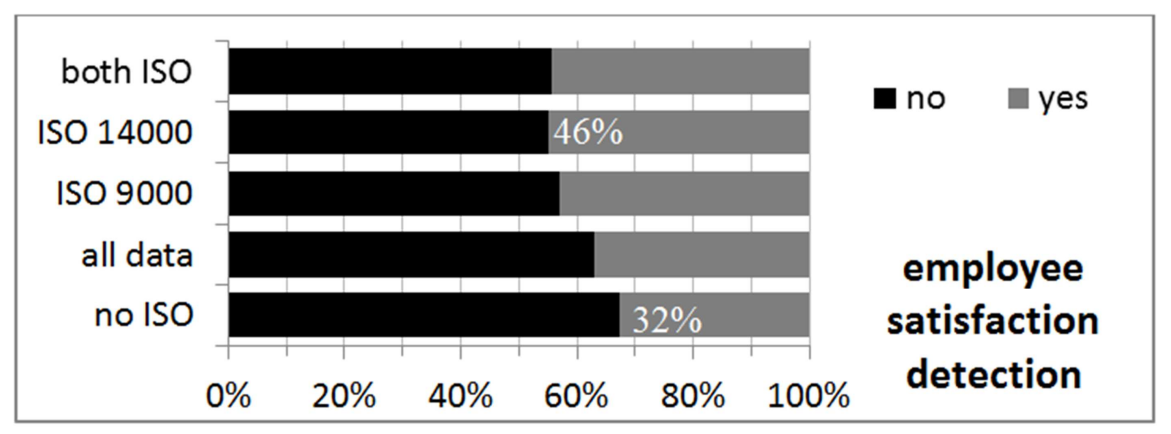

Figure 11. Evaluation of the Criterion D9 - Have the Company Researched or Measured Employees' Satisfaction?

$46 \%$ of the enterprises which implemented ISO 14000 realized measurement of employees' satisfaction, and only $32 \%$ which did not implement ISO EMS realized measurement of employees' satisfaction, so the maximum-minimum difference is $14 \%$. A similar positive trend shows also ISO 9000 and both ISO implemented data groups. 
ISO 9000 and 14000 Management Systems and Sustainability Issues of Energetic and Material Savings and Application of Renewable Sources
Five criteria concerning issues of energetic and material savings and application of renewable sources are evaluated below.

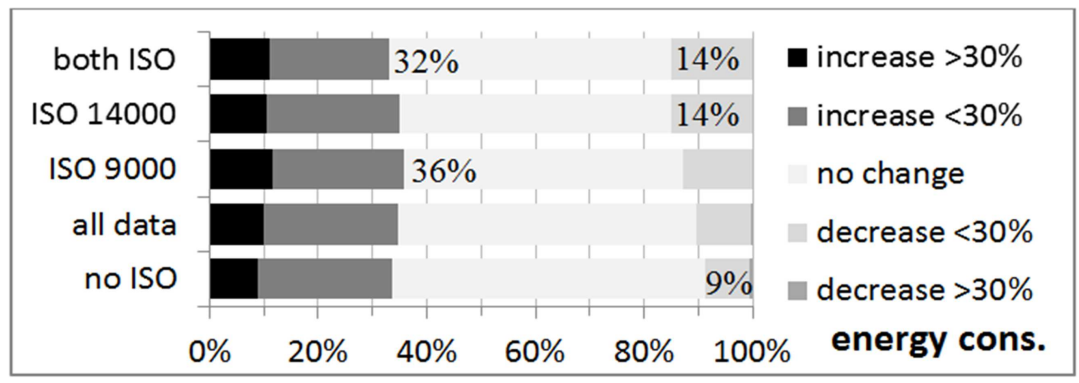

Figure 12. Evaluation of the Criterion G7 - How Period 2009-2011 Influenced Energy Consumption?

As much as $36 \%$ of the enterprises which implemented ISO 9000 indicated increased energy consumption, and 32\% which did implement both ISO EMS indicated increased energy consumption, so the maximumminimum difference is $4 \%$. A similar low rate (33\%) of increased energy consumption indicated enterprises which did not implement any ISO EMS too. On the other hand, $14 \%$ of the enterprises which implemented either both ISO EMS or ISO 14000 indicated decreased energy consumption with comparison to $9 \%$ which did not implement any ISO EMS and indicated decreased energy consumption, so the maximum-minimum difference is $5 \%$. A similar trend shows also ISO 9000 data group. A summary observation is that implementation of ISO 9000 has a slightly negative effect on energy consumption, and implementation of ISO 9000 or both ISO data group has a slightly positive effect on energy consumption.

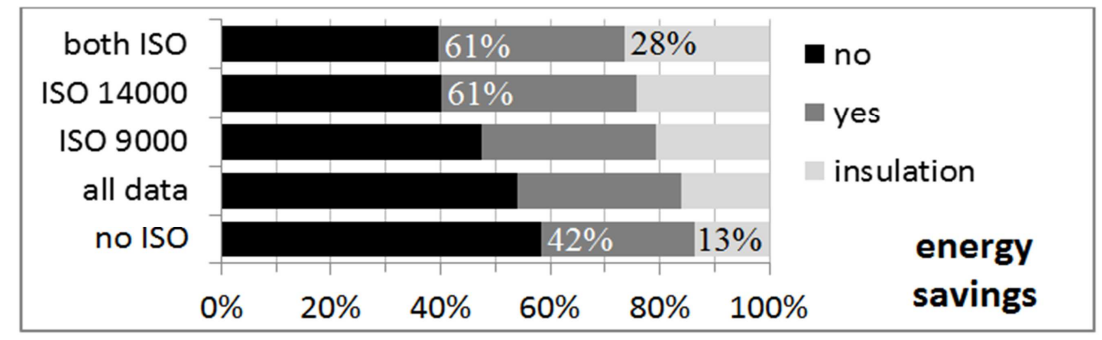

Figure 13. Evaluation of the Criterion G2 - Have You Realized Arrangements for Energy Savings?

$61 \%$ of the enterprises which implemented either both ISO EMS or ISO 14000 realized arrangements for energy savings, and only $42 \%$ which did not implement any ISO EMS realized arrangements for energy savings, so the maximum-minimum difference is $19 \%$. Also $28 \%$ of the enterprises which implemented both ISO EMS made thermal insulations on their facilities with comparison to $13 \%$ enterprises which did not implement any ISO EMS and made thermal insulations on their facilities, so the maximum-minimum difference is $15 \%$. 


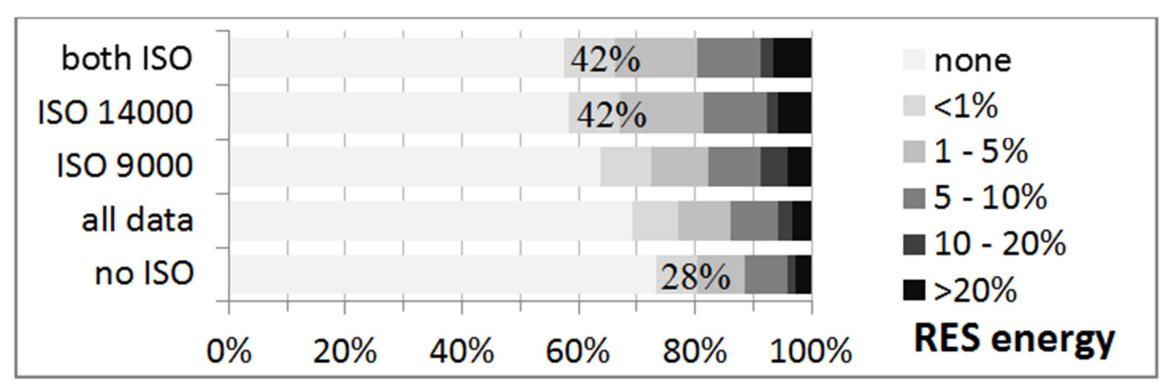

Figure 14. Evaluation of the Criterion G9 - What Percentage of Needed Energy Do You Obtain from RES?

$42 \%$ of the enterprises which did implement either both ISO EMS or ISO 14000 obtain energy from RES and only 28\% which did not implement any ISO EMS obtain energy from RES, so the maximum-minimum difference is $14 \%$.Structure of RES applied by respondents (according to the complementary question G3: what kind of RES do you apply?) is as the following: (a) LPG: $10-12 \%$, (b) solar heating: $8-10 \%$, (c) photovoltaics: $3-5 \%$, (d) other: $2-8 \%$.

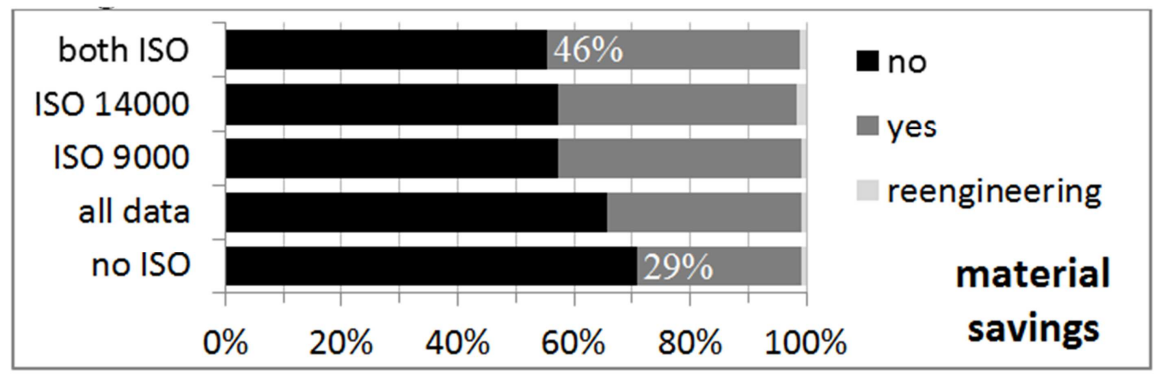

Figure 15. Evaluation of the Criterion G8 - Have You Realized Arrangements for Material Savings?

$46 \%$ of the enterprises which implemented both ISO EMS realized arrangements for material savings and only $29 \%$ which did not implement any ISO EMS realized arrangements for material savings, so the maximum-minimum difference is $17 \%$. Reengineering of production realized circa $2 \%$ of companies that implemented ISO 14000.

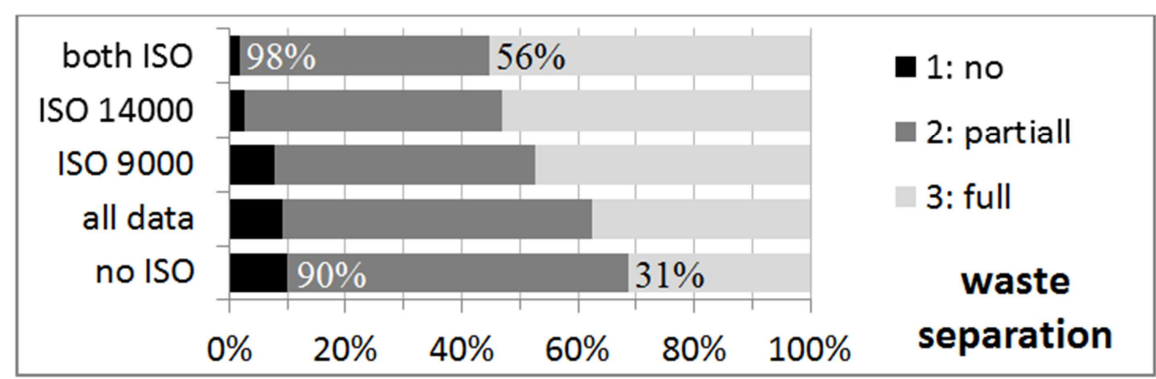

Figure 16. Evaluation of the Criterion G4 - Do You Separate and Recycle Business Waste? 
98\% of the enterprises which implemented both ISO EMS separate and recycle business waste partially and only $90 \%$ which did not implement any ISO EMS separate and recycle business waste partially, so the maximumminimum difference is $8 \%$. Also $56 \%$ of the enterprises which did implement both ISO EMS, separate and recycle business waste fully with comparison to $31 \%$ enterprises that did not implement any ISO EMS and separate and recycle business waste fully, so the maximum-minimum difference is $25 \%$.Rate of respondents using recycled material (according to the complementary question G10: How many of material inputs are recycled material?) is as the following: (a) no ISO group: up to 68\%, (b) ISO 9000 group: up to $72 \%$, (c) ISO 14000 group: up to
$78 \%$, (d) both ISO groups: up to $76 \% .43-$ $47 \%$ of the enterprises use recycled material only up to $5 \%$ of their material needs.

\section{Discussion}

\section{Validation or Dismissing of Hypotheses}

Table 1 characterizes the possible percentage of improvement (change) of performance in criteria C1-G4 according to the comparison analysis results due to the implementation of ISO management systems. Percent values show how much more successful is a group of interest (ISO 9000, ISO 14000 and both ISO) than without ISO in selected criterion. The table is used to validate hypotheses.

Table 1. Hypotheses Validation Table

\begin{tabular}{|c|c|c|c|c|}
\hline$\#$ & & HYP1 & HYP2 & HYP3 \\
\hline & & ISO 9000 & ISO 14000 & $\begin{array}{c}\text { ISO } 9000 \\
+ \text { ISO } 14000\end{array}$ \\
\hline 1 & $\mathrm{C} 1$ & $11-17 \%$ & $10-18 \%$ & $11-20 \%$ \\
\hline 2 & $\mathrm{C} 2$ & $5-9 \%$ & $4-9 \%$ & $7-13 \%$ \\
\hline 3 & $\mathrm{C} 3$ & $4-12 \%$ & $4-9 \%$ & $3-9 \%$ \\
\hline 4 & $\mathrm{C} 4$ & $9-10 \%$ & $8-13 \%$ & $9-14 \%$ \\
\hline 5 & C6 & $8-14 \%$ & $16 \%$ & $18-19 \%$ \\
\hline 6 & D3* & $(-9)-4 \%$ & $(-10)-2 \%$ & $(-11)-0 \%$ \\
\hline 7 & D2 & $(-2)-1 \%$ & $(-3)-1 \%$ & $(-2)-1 \%$ \\
\hline 8 & D1 & $2 \%$ & $0-5 \%$ & $1-5 \%$ \\
\hline 9 & D9 & $13 \%$ & $14 \%$ & $13 \%$ \\
\hline 10 & G7 & $(-3)-3 \%$ & $(-1)-5 \%$ & $1-5 \%$ \\
\hline 11 & G2 & $10 \%$ & $19 \%$ & $19 \%$ \\
\hline 12 & G9 & $8 \%$ & $14 \%$ & $14 \%$ \\
\hline 13 & G8 & $15 \%$ & $15 \%$ & $17 \%$ \\
\hline \multirow[t]{6}{*}{14} & G4 & $2-17 \%$ & $7-22 \%$ & $8-25 \%$ \\
\hline & & & & \\
\hline & Difference: & $<(-3) \%$ & Significance: & NEGATIVE \\
\hline & Difference: & $(-3)-3 \%$ & Significance: & LOW \\
\hline & Difference: & $3-10 \%$ & Significance: & MEDIUM \\
\hline & Difference: & $>10 \%$ & Significance: & HIGH \\
\hline
\end{tabular}

*Negative influence indicated

HYP1: 4 out of 14 criteria indicated high significance and 6 out of 14 criteria indicated medium significance (see table 1 ). Only 3 out of 14 criteria indicated low significance and one criterion indicated negative influence.
Application of ISO 9000 management system has positive effect on stability of business in the sustainability context on the basis of selected criteria - hypothesis confirmed. 
HYP2: 6 out of 14 criteria indicated high significance and 4 out of 14 criteria indicated medium significance (see Table 1). Only 3 out of 14 criteria indicated low significance and one criterion indicated negative influence. Application of ISO 14000 management system has positive effect on stability of business in the sustainability context on the basis of selected criteria - hypothesis confirmed.

HYP3: 6 out of 14 criteria indicated high significance and 4 out of 14 criteria indicated medium significance (see Table 1). Only 3 out of 14 criteria indicated low significance and one criterion indicated negative influence. Moreover, implementation of both ISO and QMS shows better performance in 7 criteria (C1, C2, C4, D1, G8 and G4), the same or very similar in 6 criteria (C3, D2, D9, G7, G2 and G9) and worse in 1 criterion (D3) than the implementation of ISO 9000 or ISO 14000 separately. Application of ISO 9000 and ISO 14000 management systems has synergetic positive effect on stability of business in the sustainability context on the basis of selected criteria - hypothesis confirmed.

\section{Opinion of Other Related Research Studies}

Kaynak explains that findings of his study, as well as of other research studies, support the positive effect of TQM practices on firms' performance. A lack of top management commitment to the implementation of TQM has emerged as a possible reason for the failure of TQM systems in some organizations (Kaynak, 2003). In Samson's opinion, three of the elements of TQM (leadership, people management and customer focus) have a significant positive effect on performance, but the other three categories (strategic quality planning, information and analysis and process management) do not (Samson, 1999). According to Mizla's research of costs connected with quality, the highest operational profit reaches companies, which have higher fix costs on quality than variable costs on quality (Mizla, 2012). This indirectly impliesthat, companies which invested higher amount into quality prevention
(QMS), do not have so high direct costs on quality (failures) and their economic performance is higher. Development of small- and medium-sized enterprises in Czech Republic requires investment in innovations and human resources' development (Lundström, 2008). This statement resonates well with evaluated criteria C4 (investments), G2 (energy savings) and G8 (material savings). Němeček presented research results confirming, that added value, profit and work productivity are better when enterprises employ advanced technologies as TQM (ISO 9000), CNC, JIT, CRM and EAP (Němeček, 2011).

Koc pointed out that, findings of his research suggest a fit between ISO 9000 practices, manufacturing performance, competitive priorities and firm performance (Koc, 2007). Sharma concluded that the results of his study provide evidence that ISO 9000 certification is associated with improvements in financial performance especially in profit margin, growth of sales and earnings (Sharma, 2005).

The environment performance of SMEs and their long-term commitment to managing their environmental impacts must be increased and supported through simple, effective and strategic support systems (Burke, 2006). The study of Iraldo shows that, positive effect of well-implemented EMS on resource productivity, market performance and intangible assets is visible, however not strongly supported by statistical analysis. The EMSs in spite of their application in many years, have not yet achieved a high degree of "maturity" in their implementation (Iraldo, 2009). Numerous internal and external benefits are expected from the implementation of EMS. Communication channels, skills, knowledge and attitude are all improved in SMEs adopting EMS. EMS implementations open up new interactions between staff and management and provide intangible benefits like enhanced morale, which is deemed very important (Zorpas, 2010). Hillary concluded that extensive benefits accrue to SMEs 
adopting formal EMSs and this is widely reported in the analyzed studies. Disbenefits also exist, although there are less of them (Hillary, 2004). Ilomäki explains that the environmental management systems in Finland conditions are good tools for SMEs to reach their statutory requirements. However, EMSs do not appear to provide much impetus for SMEs to implement waste minimization (Ilomäki, 2001).

MacDonald discusses that corporations need a clear framework to effectively grapple with the challenge of moving toward a sustainable society. Furthermore, tools such as ISO 140001, while a useful start, do not in themselves assist an organization in strategic planning with true sustainability in mind (MacDonald, 2005). Gupta states that past research on sustainability has evaluated the role played by the approach of sustainability in driving green initiatives adopted by firm managers and the ability of opportunities created by the firm as a result of these initiatives to drive superior performance (Gupta, 2012). Sustainable management of all social, environmental and economic aspects within a company is increasingly becoming the norm and a requirement for SMEs to operate on business. By implementing a sustainability network within a real commitment towards improved performance, benefits to bottom line will result, improving the efficiency of operations, communication and interaction with stakeholders, and reduced negative effects on society and the environment. Existing tools and strategies that assist in the implementation of ISO 14001 still remain fragmented, trying to solve the ailmentsof all SMEs (Burke, 2007).

Many operations management tools, for example total quality management, ISO 9000 standards, excellence models and common assessment framework, reengineering, six sigma, lean systems, which are based on business process management techniques, increase structuring of organizational processes. Over-standardization of organizational processes is a reduced ability of organizational process members to adjust their behavior according to changes in the environment because of formally and informally imposed rules. Accumulation of rules and standards happens due to repetition, imposition and adoption of "structure-intensive" social and physical technologies (Wilkas, 2011).

\section{Conclusion}

Realized research brought interesting results, supporting the legitimacy of implementation ISO 9000 and 14000 in order to improve company's performance. Hypotheses confirmed expected results, however seen from new perspective. Both ISO systems help to improve enterprise performance, however adopting ISO 14000 is rather a second step after implementation of ISO 9000; most enterprises with ISO 14000 adopted earlier ISO 9000 standard.

It is possible to find in literature some quality and environmental systems ex-post evaluation studies, which merely consider these systems as generally beneficial, however likewise burdened by some imperfections. ISO 9000 seems to be more widely accepted and tuned-up system than younger ISO 14000.

\section{Acknowledgement}

This paper was published and described research was realized with the support of students' grant system by Silesian University in Opava, grant number SGS/9/2012.

\section{References}

Barnes, F. (2000). "Good Business Sense Is the Key to Confronting ISO 9000," Review of Business.

Burke, S. \& Gaughran, W. F. (2006). "Intelligent Environmental Management for SMEs in Manufacturing," Robotics and Computer-Integrated Manufacturing, Nr. 22, pp. 566-575, Elsevier. 
Burke, S. \& Gaughran, W. F. (2007). "Developing a Framework for Sustainability Management an Engineering SMEs," Robotics and Computer-Integrated Manufacturing, Nr. 23, pp. 696-703, Elsevier.

Gupta, S. \& Kumar, V. (2012). "Sustainability as Corporate Culture of Brand for Superior Performance," Journal of World Business, (in press), Elsevier.

Hillary, R. (2004). "Environmental Management Systems and the Smaller Enterprise," Journal of Cleaner Production, Nr. 12, pp. 561-569, Elsevier.

Ilomäki, M. \& Melanen, M. (2001). "Waste Minimization in Small and Medium-Sized Enterprises - Do Environmental Management Systems Help?," Journal of Cleaner Production, Nr. 9, pp. 209-217, Elsevier.

Iraldo, F., Testa, F. \& Frey, M. (2009). "Is an Environmental Management System Able to Influence Environmental and Competitive Performance? The Cease of the EcoManagement and Audit Scheme (EMAS) in European Union," Journal of Cleaner Production, Nr. 17, pp. 1444-1452, Elsevier.

ISO (2009). 'Environmental Management. The ISO 14000 Family of International Standards,' [online], http://www.iso.org/iso/home/standards/m anagement-standards/iso_9000.htm

ISO (2009). Selection and Use of the ISO 9000 Family of Standards, [online], http://www.iso.org/iso/home/standards/m anagement-standards/iso14000.htm

Kaynak, H. (2003). "The Relationship between Total Quality Management Practices and their Effects on Firm Performance," Journal of Operations Management, Nr. 21, pp. 405-435, Elsevier.
Kočišová, K. \& Tartal'ová, A. (2010). 'Podnikatel'ské Prostredie a Podnikatel'ský Index Malých a Stredných Podnikov na Slovensku,' Acta Academica Karviniensia, Karviná.

Koc, T. (2007). "The Impact of ISO 9000 Quality Management Systems on Manufacturing," Journal of Materials Processing Technology, Nr. 186, pp. 207-213, Elsevier.

Koval'ová, M. (2011). 'Vybrané Problémy Implementácie Systému Riadenia Strategickej a Operatívnej Výkonnosti Podnikových Procesov,' Acta Academica Karviniensia, Karviná.

Lundström, A., Almerud, M. \& Stevenson, L. (2008). 'Entrepreneurship and Innovation Policies - Analyzing Policy Measures in European Countries,' IPREG.

MacDonald, J. P. (2005). "Strategic Sustainable Development Using the ISO 14001 Standard," Journal of Cleaner Production, Nr. 13, pp. 631-643, Elsevier.

Mizla, M. \& Pudło, P. (2012). "Štruktúra Nákladov Kvality a Citlivost' Podnikov na Výkyvy Ekonomiky," E+M Economics and Management, Liberec.

Němeček, J., Čebišová, K. \& Hribik, J. (2011). 'Comparing Economic Indicators of Companies in Dependence on Using Advanced Technologies,' Hradec economic days 2011 - conference paper collection, Hradec Králové

Nenadál, J. \& Noskievičová, D. (2005). “Moderní Systémy Řízení Jakosti - Quality Management," Management Press, Praha.

Pawliczek, A. (2011). "Udržitelný Rozvoj Vybrané Aspekty z Oblasti Podnikání," $O P F$ SU Karviná. 
Pawliczek, A. \& Piszczur, R. (2011). 'Význam Strategického Ř́zení pro Stabilizaci Podniku v Kontextu Udržitelného Rozvoje, Ekonomika a Právo - Synergie Nebo Antagonizmus?,' 6th annual international conference; Periodica Academica VŠKE, Brno.

Pawliczek, A., Rylková, Z., Šebestová, J., Antonová, B., Piszczur, R. \& Veselá, K. (2011). 'Adaptabilita Podnikání v Reakci na Turbulentní Politicko-Ekonomické Prostředí a Technologický Pokrok v Kontextu Udržitelného Rozvoje,' (research report), OPF SU Karvina.

Samson, D. \& Terziovski, M. (1999). "The Relationship between Total Quality Management Practices and Operational Performance," Journal of Operations Management, Nr. 17, pp. 393-409, Elsevier.

Scott, J. T. (2010). 'The Sustainable Business,' First Edition, European Foundation for Management Development (EFMD), Brussels.

Šebestová, J. (2012). 'Strategy and Sustainable Business Development: Dynamic Hazard or Dynamic Mania? Lessons Learned from a Crisis,' 2nd International Conference on Leadership, Technology and Innovation Management, Procedia Social and Behavioral Sciences,(in press), Istanbul.

Sharma, D. S. (2005). "The Association between ISO 9000 Certification and Financial Performance," The International Journal of Accounting, Nr. 40, pp. 151-172, Elsevier.

Wade, J. (2002). "Is ISO 9000 Really a Standard?," ISO Management Systems, [online], www.iso.org.

Wilkas, M. (2011). 'Over-Standardization of Organizational Processes,' The Journal of Economics and Management, Nr. 16, pp. 992999, Kaunas.

Zakrzewska-Bielawska, A. (2011). 'Wyzwania Rozwojowe Małych i Średnich Przedsiębiorstw - Innowacje,' Technologie, kryzys, Difin, Warszawa.
Zorpas, A. (2010). "Environmental Management System as Sustainable Tools in the Way of Life for the SMEs and VSMEs" Bioresource Technology, Nr. 101, pp. 154415757, Elsevier. 